\title{
ANOTASI BIBLIOGRAFI \\ Smartphone Sebagai Sarana Pendidikan Sejrah
}

\author{
Oleh \\ Apria Herdi \\ Email:1710111310002@mhs.ulm.ac.id \\ Program Studi Pendidikan Sejarah Fakultas Keguruan dan Ilmu Pendidikan \\ Universitas Lambung Mangkurat \\ Banjarmasin
}

Susanto, H. 2014. Seputar Pembelajaran Sejarah: Isu, Gagasan dan Strategi Pembelajaran.

Yogyakarta: Aswaja Pressindo.

Dalam buku ini mebahas tentang pembelajaran sejarah yang berkembang mengikuti perkembangan zaman. Bukan hanya itu buku ini juga menyajikan bermacam hal informasi seperti seperti melalui Pendidikan Sejarah kita sebagai manusia bisa membangun karakter bangsa selain itu pendidikan sejarah jugaberperan penting dalam penanaman rasa nasiolisme, Kemudian terdapat juga desain, perencanaan, strategi dan evaluasi dari pembelajaran sejarah yang erat hubungan nya apabila akan membuat model pembelajaran sejarah yang baru, Sehingga pembelajaran tidak terkesan monoton dan terasa memebosankan.

Susanto, H., \& Akmal, H. 2018. Efektivitas Penggunaan Aplikasi Pembelajaran Berbasis Mobile Smartphone Sebagai Media Pengenalan Sejarah Lokal Masa Revolusi Fisik di Kalimantan Selatan Pada Siswa Sekolah Menengah Atas. Historia: Jurnal Program Studi Pendidikan Sejarah, Vol.6, No.2, 197-206.

Artikel ini mempelajari tentang bagaimana cara menerapkan media pemebelajaran sejarah berbasis Smartphone untuk memperkenalkan sejarah lokal dan berfokus pada masa revolusi fisik di Kalimantan Selatan. Selain itu terdapat juga cara penggunaan Smartphone sebagai media pembelajaran sejarah untuk anak - anak sekolah menengah keatas agar pembelajaran sejarah semakin menarik. Apa lagi di era sekarang ini banyak anak - anak yang telah mengenal teknologi

Susanto, H. 2019. Media Pembelajaran Sejarah Era Teknologi Informasi (Konsep Dasar, Prinsip Aplikatif, Dan Perancangannya). Banjarmasin: FKIP Universitas Lambung Mangkurat.

Buku ini memuat berbagai macam hal menarik seputar media pembelajaran sejarah di era teknologi sekrang ini. Selain itu buku ini juga bersisi tentang konsep dari 
pemebelajaran sejarah yang meliputi sumber belajar, alat peraga, klasifikasi hingga fungsi dari Gadget sebagai media dari pembelajaran sejarah. Kemudian dilanjutkan dengan prinsip-prinsip yang bersifat aplikatif terhadap media pembelajaran dimulai dari konseptual media itu sendiri, konseptual media, hingga multimedia pembelajaran sejarah. Buku ini juga berisi tentanng bagaimana kita merancang sebuah media pembelajaran di era sekarang ini terutama media berbasis mobile smartphone.

\section{Simpulan Konseptual Anotasi Bibliografi}

Di era serba teknologi seperti sekarang ini smartphone sudah menjadi sebuah kewajiban bagi setiap orang, mungkin sudah sedikit orang-orang di dunia ini yang tidak memiliki smartphone karena sekarang apapun sudah berbasis digital dan smartphone adalah salah satu media unuk menjalankannya. Smartphone atau yang bisa disebut sebagai telpon pintar merupakan media yang kemunculannya mulai meningkatSebagai Media Pembelajaran Sejarah, Smartphone berperan penting untuk siswa/siswi untuk mempelajari Sejarah. Karena mereka tidak hanya berpaku pada buku dan literatur-literatur sejarah yang biasanya sangat tebal sementara minat baca masih sangat sedikit disini. Smartphone juga berfungsi sebagai sumber informasi dengan munculnya mesin pencarian Google. Siswa/siswi dengan mudah dapat mencari informasi seputar Sejarah dari sana yang informasinya tergolong lumayan akurat walaupun tidak semua informasi dari sana 100\% akurat maka dari itu siswa/siswi juga harus membaca buku-buku seputar sejarah agar tidak terpaku pada Google saja. Selain itu guru-guru maupun dosen juga bisa membuat aplikasi untuk pembelajaran Sejarah yang bisa digunakan di smartphone murid-murid nya. Tujuannya agar mereka tidak perlu membawa banyak buku ke sekolah atau kampus karena di dalam aplikasi itu sudah banyak materi-materi yang tersedia walaupun tidak terlalu lengkap paling tidak dapat meringankan mereka dalam hal pembelajaran Sejarah. 